\title{
12 References
}

1 Allen J, Price E, Svab I, Windak A. Framework for continuing educational development of trainers in general practice/family medicine in Europe. Cracow: EURACT, 2012.

2 WHO. World Health Report. Primary health care: now more than ever. Geneva: WHO, 2008.

3 Starfield B. Primary care: an increasingly important contributor to effectiveness, equity, and efficiency of health services. SESPAS report 2012. Gac Sanit 2012;26(Suppl1):20-6.

4 Heyrman, J, ed. EURACT Educational Agenda. Leuven: European Academy of Teachers in General Practice EURACT, 2005.

5 Starfield B. Primary care: Balancing health needs, services and technology. Oxford: Oxford University Press, 1998.

6 Fahy N. Who is shaping the future of European health systems? BMJ 2012;344:e1712.

7 Allen J, Price E, Svab I, Windak A. Framework for continuing educational development of trainers in general practice/family medicine in Europe. Cracow: EURACT, 2012.

8 WONCA Europe. European definition of family medicine. 2002.

9 Heyrman, J, ed. EURACT Educational Agenda. Leuven: European Academy of Teachers in General Practice EURACT, 2005.

10 Heyrman, J, ed. EURACT Educational Agenda. Leuven: European Academy of Teachers in General Practice EURACT, 2005.

11 Heyrman, J, ed. EURACT Educational Agenda. Leuven: European Academy of Teachers in General Practice EURACT, 2005.

12 EURACT Statement on Undergraduate Teaching in Family Medicine in all European Universities, April 2014. http://www.euract.eu/others/ finish/20-others/299-euract-statement-on-undergraduate-teaching-infamily-medicine-in-all-european-universities-april-2014

13 Wilm S. From medical school to retirement. Eur J Gen Pract 1996;2(2):7781.

14 Allen J, Price E, Svab I, Windak A. Framework for continuing educational development of trainers in general practice/family medicine in Europe. Cracow: EURACT, 2012. 
15 Brekke M, Carelli F, Zarbailov N, Javashvili G, Wilm S, Timonen M, Tandeter $\mathrm{H}$. Undergraduate medical education in general practice/family medicine throughout Europe - a descriptive study. BMC Medical Education 2013;13:157.

16 Basak O, Yaphe J, Spiegel W, Wilm S, Carelli F, Metsemakers JF. Early clinical exposure in medical curricula across Europe: an overview. Eur J Gen Pract 2009;15(1):4-10.

17 Tandeter H, Carelli F, Timonen M, Javashvili G, Basak O, Wilm S, Zarbailov N, Spiegel W, Brekke M. A “minimal core curriculum” for family medicine in undergraduate medical education: A European Delphi survey among EURACT representatives. Eur J Gen Pract 2011;17:217-20.

18 Heyrman, J, ed. EURACT Educational Agenda. Leuven: European Academy of Teachers in General Practice EURACT, 2005.

19 Wilm S, ed. EURACT checklist for attachment program organizers. European Academy of Teachers in General Practice Leuven: EURACT, 2005.

20 http://www.euract.eu/resources/specialist-training

21 Allen J, Price E, Svab I, Windak A. Framework for continuing educational development of trainers in general practice/family medicine in Europe. Cracow: EURACT, 2012.

22 http://www.euract.eu/resources/cme-cpd

23 Miller GE. The assessment of clinical skills/competence/performance. Acad Med 1990;65(Suppl.):S63-7.

24 Rethans JJ, Norcini JJ, Baron-Maldonado M, Blackmore D, Jolly BC, LaDuca T, et al. The relationship between competence and performance: Implications for assessing practice performance. Med Educ 2002;36:901-9.

25 Rethans JJ, Norcini JJ, Baron-Maldonado M, Blackmore D, Jolly BC, LaDuca $\mathrm{T}$, et al. The relationship between competence and performance: Implications for assessing practice performance. Med Educ 2002;36:901-9.

26 Rethans JJ, Norcini JJ, Baron-Maldonado M, Blackmore D, Jolly BC, LaDuca $\mathrm{T}$, et al. The relationship between competence and performance: Implications for assessing practice performance. Med Educ 2002;36:901-9.

27 Rethans JJ, Norcini JJ, Baron-Maldonado M, Blackmore D, Jolly BC, LaDuca $\mathrm{T}$, et al. The relationship between competence and performance: Implications for assessing practice performance. Med Educ 2002;36:901-9.

28 Campion P. Can you compare competence and performance? A reply to McKinstry et al. Family Practice 2004;21:81-2. 
29 Rethans JJ, van Leeuwen Y, Drop R, van der Vleuten C, Sturmans F. Competence and performance: Two different concepts in the assessment of quality of medical care. Family Practice 1990;7(3):168-74.

30 Starfield B. Toward international primary care reform. Can Med Assoc J 2009;180(11):1091-2.

31 Heyrman, J, ed. EURACT Educational Agenda. Leuven: European Academy of Teachers in General Practice EURACT, 2005.

32 Finucane PM, Bourgeois-Law GA, Ineson SL, Kaigas, TM. A comparison of performance assessment programs for medical practitioners in Canada, Australia, New Zealand, and the United Kingdom. Acad Med 2003;78:837-43.

33 Schuwirth LWT, Southgate L, Page GG, Paget NS, Lescop JMJ, Lew SR, et al. When enough is enough: a conceptual basis for fair and defensible practice performance assessment. Med Educ 2002;36:925-30.

34 Van der Vleuten CPM, Schuwirth LWT, Driessen EW, Dijkstra J, Tigelaar D, Baartman LKJ, et al. A model for programmatic assessment fit for purpose. Medical Teacher 2012;34:205-14.

35 Parkerton PH, Smith DG, Belin TR, Feldbau GA. Physician performance assessment: nonequivalence of primary care measures. Medical Care 2003;41(9):1034-47.

36 Finucane PM, Bourgeois-Law GA, Ineson SL, Kaigas, TM. A comparison of performance assessment programs for medical practitioners in Canada, Australia, New Zealand, and the United Kingdom. Acad Med 2003;78:837-43.

37 Finucane PM, Barron SR, Davies HA, Hadfield-Jones RS, Kaigas TM. Towards an acceptance of performance assessment. Med Educ 2002;36:959-64.

38 Schuwirth LWT, Southgate L, Page GG, Paget NS, Lescop JMJ, Lew SR, et al. When enough is enough: a conceptual basis for fair and defensible practice performance assessment. Med Educ 2002;36:925-30.

39 Rethans JJ, Gorter S, Bokken L, Morrison L. Unannounced standardised patients in real practice: a systematic literature review. Medical Education 2007:41:537-49.

40 Overeem K, Faber MJ, Arah OA, Elwyn G, Lombarts KM, Wollersheim HC, et al. Doctor performance assessment in daily practise: does it help doctors or not? A systematic review. Med Educ 2007;41:1039-49.

41 Govaerts $\mathrm{M}$ et al. Broadening perspectives on clinical performance assessment: Rethinking the nature of in-training assessment. Adv in Health Sci Educ 2006;12:239-60. 
42 Kogan JR, Holmboe ES, Hauer KE. Tools for direct observation and assessment of clinical skills of medical trainees: a systematic review. JAMA 2009;302:1316-26.

43 Pelgrim E et al. In-training assessment using direct observation of single-patient encounters: a literature review. Adv in Health Sci Educ 2011;16:131-42.

44 Miller A, Archer J. Impact of workplace based assessment on doctors' education and performance: a systematic review. BMJ 2010;341:c5064.

45 Van den Hombergh P, Grol R, van den Hoogen HJ, van den Bosch WJ. Practice visits as a tool in quality improvement: acceptance and feasibility. Qual Health Care 1999;8:167-71.

46 WONCA Europe. European definition of family medicine. 2002.

47 Heyrman, J, ed. EURACT Educational Agenda. Leuven: European Academy of Teachers in General Practice EURACT, 2005.

48 EQuiP, EURACT. Continuing professional development in primary health care. Quality development integrated with continuing medical education. Policy Document of EQuiP and EURACT, 2002.

49 Miller GE. The assessment of clinical skills/competence/performance. Acad Med 1990;65(Suppl.): S63-S7.

50 Norcini JJ. Current perspectives in assessment: the assessment of performance at work. Med Educ 2005;39:880-9.

51 Govaerts MJB, Van der Vleuten CPM, Schuwirth LWT, Muijtjens AMM. Broadening perspectives on clinical performance assessment: rethinking the nature of in-training assessment. Adv in Health Sci Educ 2007;12:23960 .

52 Govaerts MJB et al. Workplace-based assessment: effects of rater expertise. Adv in Health Sci Educ 2011;16:151-65.

53 Van der Vleuten CPM. The assessment of professional competence: building blocks for theory development. Best Practice \& Research Clinical Obstetrics and Gynecology 2010;24:703-19.

54 Norman G. Research in clinical reasoning: past history and current trends. Med Educ 2005;39(4):418-27.

55 Norcini JJ, Swanson DB, Grosso LJ, Webster GD. Reliability, validity and efficiency of multiple choice questions and patient management problems item formats in the assessment of medical competence. Med Educ 1985;19:238-47. 
56 Margolis MJ, Clauser BE, Swanson DB, Boulet JR. Analysis of the relationship between score components on a standardized patient clinical skills examination. Acad Med 2003;78(10 Suppl):S68-71.

57 Eva KW, Hodges B. Scylla or Charybdis? Can we navigate between objectification and judgment in assessment? Med Educ 2012;46;914-9.

58 Petrusa ER. Clinical Performance Assessment. In: Norman R, Van der Vleuten CPM, Newlbe DI (eds). International handbook for research in medical education. Kluwer Academic Publishing 1997. pp673-709.

59 Regehr $\mathrm{G}$ et al. Comparing the psychometric properties of checklist and global rating scales for assessing performance on an OSCE-format examination. Acad Med 1998;73(9):993-7.

60 Van der Vleuten CPM. The assessment of professional competence: building blocks for theory development. Best Practice \& Research Clinical Obstetrics and Gynecology 2010;24:703-19.

61 Van der Vleuten CPM. The assessment of professional competence: Developments, research and practical implications. Adv in Health Sci Educ 1996;1:41-67.

62 Petrusa ER. Clinical Performance Assessment. In: Norman R, Van der Vleuten CPM, Newlbe DI (eds). International handbook for research in medical education. Kluwer Academic Publishing, 1997. pp673-709.

63 Van der Vleuten CPM. The assessment of professional competence: Developments, research and practical implications. Adv in Health Sci Educ 1996;1:41-67.

64 Schuwirth LWT, Van der Vleuten CPM. Different written assessment methods: what can be said about their strengths and their weaknesses? Med Educ 2004;38(9):974-9.

65 Kreiter C, Green J, Lenoch S, Saiki T. The overall impact of testing on medical student learning: quantitative estimation of consequential validity. Adv in Health Sci Educ 2012;DOI 10.1007/s10459-012-9395-715

66 Cilliers FJ, Schuwirth L, Adendorff $\mathrm{H}$. The mechanism of impact of summative assessment on medical students' learning. Adv in Health Sci Educ 2010;15:695-715.

67 Mc Lachlan JC. The relationship between assessment and learning. Med Educ 2006;40(8): 716-17.

68 Kluger A, DeNisi A. The effects of feedback interventions on performance: a historical review, a meta-analysis, and a preliminary feedback intervention theory. Psychol Bull 1996;119:254-84. 
69 Kreiter C, Green J, Lenoch S, Saiki T. The overall impact of testing on medical student learning: quantitative estimation of consequential validity. Adv in Health Sci Educ 2012;DOI 10.1007/s10459-012-9395-715.

70 Larsen D, Butler A, Roediger H. Test-enhanced learning in medical education. Med Educ 2008;42:959-66.

71 Norcini JJ et al. Criteria for good assessment: Consensus statement and recommendations form the Ottawa 2010 Conference. Medical Teacher 2011;33:206-14.

72 Sergeant J et al. Features of assessment learners use to make informed self-assessments of clinical performance. Med Educ 2011;45:636-647.

73 Mann K, Van der Vleuten CPM, Eva KW, Armson H, Chesluk B et al. Tensions in informed self-assessment: How the desire for feedback and reticence to collect and use it can conflict. Acad Med 2011;86(9):1120-7.

74 Veloski J, Boex JR, Grasberger MJ, Evans A, Wolfson DB. Systematic review of the literature on assessment, feedback and physicians' clinical performance: BEME Guide No 7. Med Teach 2006;28:117-28.

75 Sargeant J et al. Reflection: a link between receiving and using assessment feedback. Adv in Health Sci Educ 2009;14:399-410.

76 Schuwirth LWT, Van der Vleuten CPM. (2011). Programmatic assessment: From assessment of learning to assessment for learning. Medical Teacher 2011;33(6):478-85.

77 Van der Vleuten CPM. The assessment of professional competence: building blocks for theory development. Best Practice \& Research Clinical Obstetrics and Gynecology 2010;24;703-19.

78 Moonen-van Loon JMW, Overeem K, Donkers HHLM, Van der Vleuten CPM, Driessen EW. Composite reliability of a workplace-based assessment toolbox for postgraduate medical education. Adv in Health Sci Educ 2013;DOI 10.1007/s10459-013-9450-z.

79 Govaerts MJB, Van der Vleuten CPM, Schuwirth LWT, Muijtjens AMM. Broadening perspectives on clinical performance assessment: rethinking the nature of in-training assessment. Adv Health Sci Educ 2007;12:239-60.

80 Bullock AD, Hassell A, Markham WA, Wall DW, Whitehouse AB. How ratings vary by staff group in multi-source feedback assessment of junior doctors. Med Educ 2009;43(6):516-20.

81 Cleland JA, Knight LV, Rees CE, Tracey S, Bond CM. Is it me or is it them? Factors that influence the passing of underperforming students. Med Educ 2008;42:800-9. 
82 Govaerts MJB, Van der Vleuten CPM, Schuwirth LWT, Muijtjens AMM. Broadening perspectives on clinical performance assessment: rethinking the nature of in-training assessment. Adv Health Sci Educ 2007;12:239-60.

83 Govaerts MJB et al. Workplace-based assessment: raters' performance theories and constructs. Adv in Health Sci Educ 2012;18(3):375-96.

84 Berendonck C, Stalmeijer R, Schuwirth LWT. Expertise in performance assessment: assessors' perspectives Adv in Health Sci Educ 2013;18(4):559-71.

85 Regehr G et al. Using "Standardized Narratives" to explore new ways to represent faculty opinions of resident performance. Acad Med 2012;87(4): 419-22.

86 Davis et al. Accuracy of physician self-assessment compared with observed measures of competence. A systematic review. JAMA 2011;296(9):1094102.

87 Eva KW, Regehr G. Self-assessment in the health professions: a reformulation and research agenda. Acad Med 2005;80(10 Suppl):S46-S54.

88 Dory V, Degryse J, de Foy T. L'auto-évaluation: postulat préalable, finalité de la mission éducative ou utopie pédagogique ? Clarifications conceptuelles et pistes pour une application en éducation médicale. Pédagogie médicale 2009;10(1):41-54.

89 Eva KW, Regehr G. "I'll never play professional football" and other fallacies of self-assessment. Journal of Continuing Education in the Health Professions 2008;28(1):14-9.

90 Sargeant J et al. Reflection: a link between receiving and using assessment feedback. Adv in Health Sci Educ 2009;14:399-410.

91 Van der Vleuten CPM, Schuwirth LWT. Assessment of professional competence: from methods to programs. Med Educ 2005;39:309-17.

92 Van der Vleuten CPM. The assessment of professional competence: building blocks for theory development. Best Practice \& Research Clinical Obstetrics and Gynecology 2010;24;703-19.

93 Van der Vleuten CPM. The assessment of professional competence: building blocks for theory development. Best Practice \& Research Clinical Obstetrics and Gynecology 2010;24;703-19.

94 McWhinney IR. A Textbook of Family Medicine. $2^{\text {nd }}$ ed. Oxford: Oxford University Press, 1997.

95 Balint M. The Doctor, his Patient and the Illness. London: Pitman Medical Publishing, 1964. 
96 Mead N, Bower P. Patient-centeredness: a conceptual framework and review of the empirical literature. Social Science \& Medicine 2000,51:1087-110.

97 Leopold N. Sustained partnership in primary care. J Fam Pract 1996;42:12937.

98 Stewart M, Brown J, Weston W, McWhinney IR, McWilliam C, Freeman T. Patient Centred Medicine. Thousand Oaks: Sage Publications, 1995.

99 Pendleton D, Schofield T, Tate P, Havelock P. The Consultation - an Approach to Learning and Teaching. New York: Oxford University Press, 1984 (reprint 1993).

100 Jamoulle M, Roland M. Quaternary Prevention. Paper presented at the Hong-Kong Meeting of the WONCA Classification Committee, June 1995.

101 Foolen CHGM, Tan LHC, Van der Vleuten CPM. Laconto - Development of a national instrument to assess consultation skills of future general practitioners. 1992.

102 Bentzen N. WONCA Dictionary of General/Family Practice. WONCA International Classification Committee, 2003.

103 Reading A. Illness and disease. Medical Clinics of North America 1977;61:703-71.

104 Balint M. The Doctor, His Patient and the Illness. New York: International University Press, 1972.

105 Newble DI, Canno R. A Handbook for Medical Teachers. $3^{\text {rd }}$ ed. Kluwer Academic Publishers, 1996.

106 EQuiP, EURACT. Continuing professional development in primary health care. Quality development integrated with continuing medical education. Policy Document of EQuiP and EURACT, 2002.

107 Conlon M. Appraisal: the catalyst of personal development. BMJ 2003;327:389-91.

108 Jelley D, van Zwanenberg T. Practice-based peer appraisal in general practice: an idea whose time has come? Education for Primary Care 2003;14:329-37.

109 http://www.rcgp.org.uk/gp-training-and-exams/mrcgp-workplace-basedassessment-wpba/cbd-for-mrcgp-workplace-based-assessment.aspx

110 http://www.rcgp.org.uk/gp-training-and-exams/mrcgp-workplace-basedassessment-wpba/cot-for-mrcgp-workplace-based-assessment.aspx

111 Miller A, Archer J. Impact of workplace based assessment on doctors' education and performance: a systematic review. BMJ 2010;341:c5064. 
112 Archer JC. State of the science in health professional education: effective feedback. Med Educ 2010;44:101-8.

113 Veloski J, Boex JR, Grasberger MJ, Evans A, Wolfson DB. Systematic review of the literature on assessment, feedback and physicians' clinical performance: BEME Guide No 7. Med Teach 2006;28:117-28.

114 Hobma SO, Ram PM, Muijtjens AMM, Grol RPTM, Van der Vleuten CPM. Setting a standard for performance assessment of doctor-patient communication in general practice. Med Educ 2004;38:1244-52.

115 http://www.rcgp.org.uk/gp-training-and-exams/mrcgp-workplace-basedassessment-wpba/psq-for-workplace-based-assessment.aspx

116 Wilkinson TJ, Challis M, Hobma SO, Newble DI, Parboosingh JT, Sibbald RG, Wakeford R. The use of portfolios for assessment of the competence and performance of doctors in practice. Med Educ 2002;36:918-24.

117 Rethans JJ, Gorter S, Bokken L, Morrison L. Unannounced standardised patients in real practice: a systematic literature review. Med Educ 2007;41:53749.

118 Miller A, Archer J. Impact of workplace based assessment on doctors' education and performance: a systematic review. BMJ 2010;341:c5064.

119 Rughani A Workplace-based assessment and the art of performance. Br J Gen Pract 2008;58:582-4.

120 http://www.gmc-uk.org/Workplace_Based_Assessment__A_guide_for_ implementation_0410.pdf_48905168.pdf

$121 \mathrm{http}: / /$ www.wpba4gps.co.uk/home/

$122 \mathrm{http}: / /$ www.amc.org.au/index.php/ass/apo/sp/wba

$123 \mathrm{http} / /$ www.faculty.londondeanery.ac.uk/e-learning/workplace-basedassessment

124 http://www.rcgp.org.uk/gp-training-and-exams/mrcgp-workplace-basedassessment-wpba.aspx

125 Wilkinson J, Crossley J, Wragg A, Mills P, Cowan G, Wade W. Implementing workplace-based assessment across the medical specialties in the United Kingdom. Med Educ 2008;42:364-73.

126 Murphy DJ, Bruce DA, Mercer SW, Eva KW. The reliability of workplace-based assessment in postgraduate medical education and training: a national evaluation in general practice in the United Kingdom. Adv in Health Sci Educ 2009;14:219-32. 


